\title{
PLP1 wt Allele
}

National Cancer Institute

\section{Source}

National Cancer Institute. PLP1 wt Allele. NCI Thesaurus. Code C75898.

Human PLP1 wild-type allele is located in the vicinity of Xq22 and is approximately $16 \mathrm{~kb}$ in length. This allele, which encodes myelin proteolipid protein, plays a role in the modulation of neuronal development and function. Mutation of the gene is associated with both Pelizaeus-Merzbacher disease and spastic paraplegia type 2. 